\title{
ERASMUS PROGRAMME EFFECTS: A SPANISH CASE
}

\section{LOS EFECTOS DEL PROGRAMA ERASMUS: UN CASO EN ESPAÑOL}

\author{
ELENA URQUÍA-GRANDE \\ Universidad Complutense de Madrid \\ eurquiag@ccee.ucm.es \\ CRISTINA DEL CAMPO \\ Universidad Complutense de Madrid \\ campocc@ccee.ucm.es \\ Fecha de recepción: febrero 2016 \\ Fecha de aceptación: abril 2016
}

\begin{abstract}
The internationalisation of Higher Education (HE), as part of the European integration programs, has become a priority not only for governments but also for universities. The Faculty of Economics and Business (Complutense University of Madrid) has promoted the European mobility as part of the internationalisation strategy through the Erasmus programs for students' mobility since its beginning. However continuous endeavour must be made. The objective of the present research is to study the internationalisation of HE. For this purpose a survey was designed to measure the degree of outgoing Erasmus students' satisfaction. Multivariate statistic techniques were run to observe that variables such as academic and cultural experiences in the host Universities determine the students' overall satisfaction. Multiple maps of relationships within variables were found demonstrating that students perceive as most important they develop academic and socio-cultural competences together with linguistic skills when studying abroad.
\end{abstract}

KEY WORDS: Internationalisation; Higher Education; European mobility; overall satisfaction.

\section{RESUMEN}

La internacionalización de la Educación Superior como parte de los programas de integración europea actualmente es una prioridad para Gobiernos y Universidades. La Facultad de Ciencias Económicas y Empresariales de la Universidad Complutense de Madrid ha promovido la movilidad internacional desde el principio. Sin embargo, su mejora continua debe proseguir. El objetivo de este artículo es estudiar la internacionalización de la Educación Superior. Para ello se ha diseñado un cuestionario para los alumnos que han recibido una beca Erasmus donde se miden diferentes aspectos. Se han aplicado técnicas multi-variantes para descubrir y diseñar mapas de relaciones entre las variables. Se ha observado que los aspectos académicos y socio-culturales son los que determinan la satisfacción global sobre la experiencia de movilidad en Europa. 
Urquía-Grande, Elena; del Campo, Cristina. Erasmus programme effects: a Spanish case.

PALABRAS CLAVE: internacionalización; Educación Superior; movilidad europea; satisfacción.

JEL: F29; 123.

\section{INTRODUCTION}

The internationalisation of Higher Education $(\mathrm{HE})$ has become an important policy not only for Governments in European countries (Beerkens, 2004) but also for universities. Currently, since students perceive themselves as international citizens, a university must continuously define and review internationalisation strategies. Additionally, the underlying rationale of exchange programmes is that by living, studying and working together Europeans become aware of their commonalities and develop a supranational identity (Papatsiba, 2005; Petit, 2007; Kuhn, 2012) as well as academic, socio-cultural adjustment and linguistic competences which are essential for their professional future (ESN, 2016; EU, 2014; Fernández, Pérez y Vaquero, 2008). Furthermore, international mobility is one of the core elements of the Bologna process, enabling the development of international cooperation and enhancing the European dimension of education (Rachaniotis et al., 2013; Fernández, Fernández and Vaquero, 2007).

The objective of the present research is to study the internationalisation of $\mathrm{HE}$ as part of the European integration from an institutional point of view, concretely from a Spanish University empirical point of view. This research will consider the students' overall satisfaction with their international academic stay, their socio-cultural adjustment perception and their mastering of a third language (besides their native language and their English proficiency) as primary outcomes. Additionally, increasing student mobility, one of the key concepts of EU educational policy, has reinforced the view that one of the most effective means to prepare future graduates' transversal skills'for the needs of international employability in a global economy is to study and live abroad (Ericsson, 2000; Papatsiba, 2009; Wilson, 2011).

The Faculty of Economics and Business of the Complutense University of Madrid (UCM) has promoted the internationalisation of HE through the Erasmus programs since its beginning; however continuous endeavour must be made. Therefore, a survey was designed to measure the degree of success among the Faculty's Erasmus outgoing students. A growing number of students want to study abroad because of the life experience, the socio-cultural skills development, language learning and academic achievement. In fact, these students represent approximately 21 per cent of the total enrolled students, which means that mobility has been successful reflecting the efforts made to promote it in the UCM although a greater internationalisation effort must be made.

Some conclusions of the present work highlight that students who study abroad develop their intercultural competence. Also, most of them improve substantially their linguistic competence in the local language of the host University and that gender plays a big role during the choice of the host country. Finally, academic and economic issues 
Urquía-Grande, Elena; del Campo, Cristina. Erasmus programme effects: a Spanish case.

are factors that determine the overall satisfaction of their exchange experience although student's personal and academic adjustment depend on the country of destination.

The structure of this paper is as follows. In section 2 we review the past literature on internationalisation's concepts and trends, a contextualization of the HE internationalisation strategy in Spain and specifically focused in the Faculty of Economics and Business (of the UCM). Section 3 presents the instrument and the sample. In section 4 the results are displayed and discussed. Finally, some interesting conclusions are drawn from the theoretical and empirical analysis in section 5.

\section{BIBLIOGRAPHIC REVIEW}

The European Commission has launched in the past 25 years different educational exchange programmes in the hope of promoting a feeling of European identity among its citizens (Corbett, 2005; Petit, 2007). The Erasmus program was started to strengthen participants' human capital and integrate the European labour market (Papatsiba, 2009). European policy-makers know the potential of education as a means of fostering the ties between the European policy and its population (Keating, 2009) as well as being an economic commodity to be used to encourage Europeans' employability and to enlarge the EU as a knowledge-based society (Pépin, 2007; Walkenhorst, 2008). Since 1987 the target of Europe to achieve mobility for over three million European students has succeeded and has received financial support from the European Agency. As a result students can study abroad knowing that the courses they take in the host university will contribute to complete their degree in their home university.

Erasmus has become one of the most highly visible EU internationalisation and integration programmes and has become iconic for Europeans, whose use of the term 'Erasmus generation' to describe young Europeans evokes a hope that European youth will prove more supportive of European mobility for academic and professional purposes than their parents or grandparents. In fact, the Erasmus generation is made up of young people who have enjoyed the practical benefits of European internationalisation, are highly mobile, think of themselves as European citizens, and are consequently a base of support for a deeper European integration. The current 'Erasmus+' programme has a new approach with the objective of developing links between mobility programmes and policy objectives, more synergies and interaction among formal and informal learning, and more partnerships with companies, enhancing employability and entrepreneurship (Musselin, 2004; European Commission, 2013).It also promotes a simpler administrative structure, additional funding and a stronger focus on EU. Added values of this programme are learning mobility of individuals, cooperation for innovation and exchange of good practices in internationalisation and support for policy reform.

Embedded within the European integration perception and Erasmus mobility program there exists the potential to foster the Intercultural Communication Competences (ICC) and prepare international students to be active members in the globalized workforce. Therefore, research in ICC as a main internationalisation HE institutional outcome has been highly developed (Knight and de Wit, 1995; Deardorff, 2006; Parsons, 2010; 
Urquía-Grande, Elena; del Campo, Cristina. Erasmus programme effects: a Spanish case.

Campbell, 2011; Bennett et al., 2013). The positive impact of intercultural interaction for international and local students has been emphasized over decades (Montgomery and McDovell, 2009; Bennett et al., 2013). However, the cultural aims of internationalisation to produce students who have developed the intercultural skills defined as an understanding of others' worldview, an awareness of cultural differences, self-awareness of one's culture and the development of generic attitudes such as openness, respect and empathy towards perceived cultural others are yet to be successfully achieved (Ericsson, 2000; Ippolito, 2007). One important reason is that there exists an implicit complexity in the integration amongst students from different backgrounds, cultures and aims in life. Additionally, research analysing factors associated with different socio-cultural adjustment experiences by international students has had great impact in HE internationalisation research (Chirkovet al., 2008; Yusliza and Shankar, 2010). Other researchers have analysed the cultural adjustment from a psychological point of view since Allport's contact hypothesis (1954) examining student intercultural interaction and competence development finding that only a minority of students form intercultural friendships at university (Halualani, 2008; Summers and Volet, 2008; Montgomery and McDovell, 2009). Finally, other researchers have found that sharing lectures and classes together with similar curriculum content is vital for initial contact and maintenance of interaction opportunities encouraging stronger bonds between classmates (Kimmel and Volet, 2012).

Internationalisation of $\mathrm{HE}$, in its beginning, was focused on developing projects, foreign students and academic agreements (Knight, 2004, 2008), enhancing HE's teaching quality, cooperation and learning (de Wit, 2011). García et al. (2013) have analysed variables that determine HE members (teachers, students, researchers...) mobility and how these determine the student's socio-cultural and linguistic competences. There are national and sector-level strategy trends going from local programs to strategic ones through rationales and policy approaches (Knight and de Wit, 1995; Fernández and Ruzo, 2003; Albatch and Knight, 2007; Knight, 2008; Brandenburg and de Wit, 2011; Agnew, 2012; Aerden et al. 2013). The national-level internationalisation includes the policies and strategies implemented from the State's point of view. The institutional approach embeds activities, outcomes, rationales and processes, at home or abroad, achieved by universities. The activities aim to enhance students studying abroad, designing curriculum and academic programs jointly with other universities and creating branch campuses abroad. Internationalisation can also be understood as implementing bilingual degrees at home so students from abroad can come to study in an English Medium Instruction (EMI) degree or can be understood as the crossborder delivery of education to other countries (distance e-learning).

Institutional-level rationales range from mission, vision, student population, faculty profile, funding sources and orientation to local, national and international interests. Faculty profile will motivate institutions to achieve a strong worldwide reputation if it is considered a high-quality university. The students and lecturer's development is the most important issue for universities as a means to enhance the international and intercultural understanding and skills. Moreover, mobility of the labour market and the increase in cultural diversity of communities and workplace require students to develop 
Urquía-Grande, Elena; del Campo, Cristina. Erasmus programme effects: a Spanish case.

skills to work in a diverse and changing environment (Fernández, Pérez and Vaquero, 2009; Papatsiba, 2009; Wilson, 2011). But also HE institutions need to produce, disseminate and publish internationally original research and knowledge in order to promote new international improvement strategies and enhance international exchanges of lecturers and researching.

In strong connection with this internationalisation process, many universities around the world are now offering English as a medium of instruction (EMI) courses, and even more so in Europe with the consolidation of the European Higher Education Area(EHEA) (Maiworm and Wächter, 2002; Dafouz et al., 2013). The introduction of English is an added value to the attractiveness of many European universities and has become the academic common language in EHEA. Regarding national settings, Northern and Central European universities have a longer experience offering these degrees, especially at postgraduate level, than Southern European universities. For instance, most of the Netherlands universities (Wilkinson, 2004; Wilkinson and Zegers, 2007) use English as the sole language of instruction, while in Norway (Hellekjaer, 2010) or Sweden (Airey, 2004, 2009; Björkman, 2010) many degrees are fully taught in English. These are the preferred destinations for the students in the Southern countries. Many students are also attracted by the possibility of developing a third language competence as an additional motivation for studying abroad for a year with an Erasmus grant (Willis, 2010).

Currently, two million HE students approximately are studying and training abroad, 650,000 from vocational training and 200,000 from master programmes. There are more than 25,000 strategic partnerships and knowledge alliances involving 125,000 institutions and firms implementing joint initiatives and promoting exchange of experience and know-how in the real world of work (European Commission, 2013). Additionally, 800,000 lecturers, teachers, trainers and education staff teach or train abroad. According to the Spanish Ministry of Education, in Spain, $\mathrm{HE}$ Internationalisation has changed since the first Erasmus Mobility Programme from being a student importer to being an exporter as well.

Drawing on the aforementioned studies, this paper will try to answer the next research questions:

- RQ1: Do students perceptions of their academic and socio-cultural adjustment differ between destination countries?

- RQ2: Do students perceive they develop a linguistic competence as an internationalisation outcome?

- RQ3: Which variables influence the students' overall satisfaction in destination universities?

- RQ4: What are the relations between the analysed variables?

2. INSTRUMENT AND SAMPLE DESCRIPTION

In this section we describe the survey instrument and the sample, including how the data was collected.

a. The instrument 
Urquía-Grande, Elena; del Campo, Cristina. Erasmus programme effects: a Spanish case.

The Faculty of Economics and Business of the UCM has promoted an internationalisation strategy throughout the Erasmus programs since its beginning. A survey was designed to measure the degree of success among the Faculty's out-going Erasmus students including several categories:

- Demographic information

- Motivation

- Received information and support

- Academic assistance

- Linguistic competence

- Economic issues, including accommodation issues

- Socio-cultural adjustment perception

- Overall satisfaction

The majority of the questions were evaluated using a seven point Likert-type scale between "I completely disagree" (value 1) and "I completely agree" (value 7) (Appendix A). There were four open questions for students to value positive and negative aspects of their Erasmus experience and to propose improvements. The survey was voluntary and was given to the students when they returned from their stay and before the students' transcript of records were passed into their academic reports. Furthermore, the aim of the survey is to be able to contrast the variables influencing the students' socio-cultural, linguistic and global adjustment in the host universities and if it is a consequence of the HE internationalisation strategy in line with Rachaniotis et al. (2013).

b. The sample

Out-going Erasmus students from academic years 2010/2011, 2011/2012 and $2012 / 2013$ were asked to fill in the survey. Out of the 541 who went abroad with an Erasmus grant in those three years only 321 returned the questionnaire, 94 out of 164 in 2010/11, 128 out of 209 in 2011/12 and 99 out of 168 in 2012/13. There were 60 per cent male students versus 40 per cent female students and the majority were born in 1990.

The students' preferred destinations were the Netherlands, Italy, France, the United Kingdom and Germany (see Figure 1). Among the many degrees offered in the faculty, most of out-going students were enrolled in the degree in Business Administration, the degree in Economics and the double degree in Law and Business Administration, their first motivation being their curriculum vitae improvement and their peers reported socio-cultural experiences abroad. 
Figure 1: Destination countries

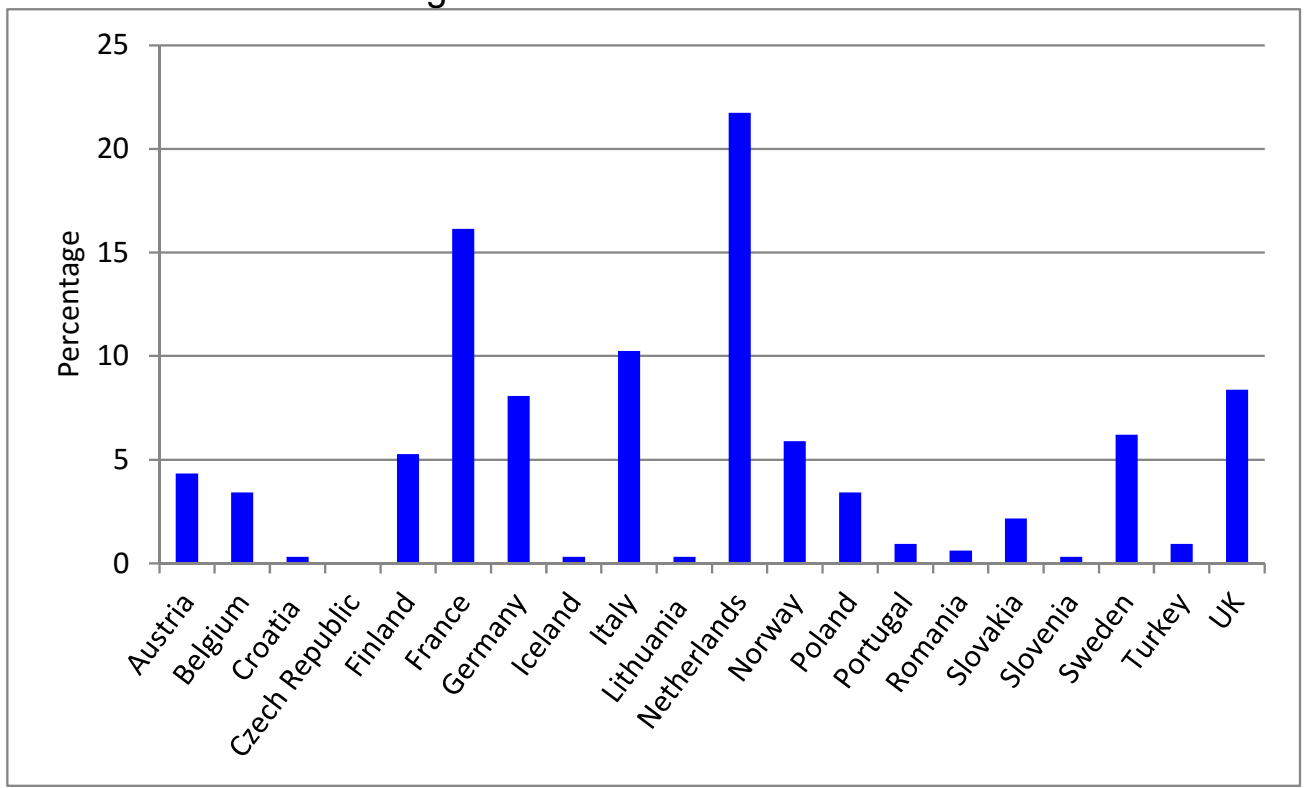

In relation with the economic aspect of the Erasmus grant 65 per cent of the students answered they needed between 501 and 1,000 $€$ more to live in the destination countries (see Figure 2). Unsurprisingly the trend is moving from spending $501-1,000 €$ to $1,001-1,500 €$, as the grants given by both the Spanish Ministryof Education and the University have considerably decreased.

Figure 2: Declared extra monthly expenditure (in Euros)

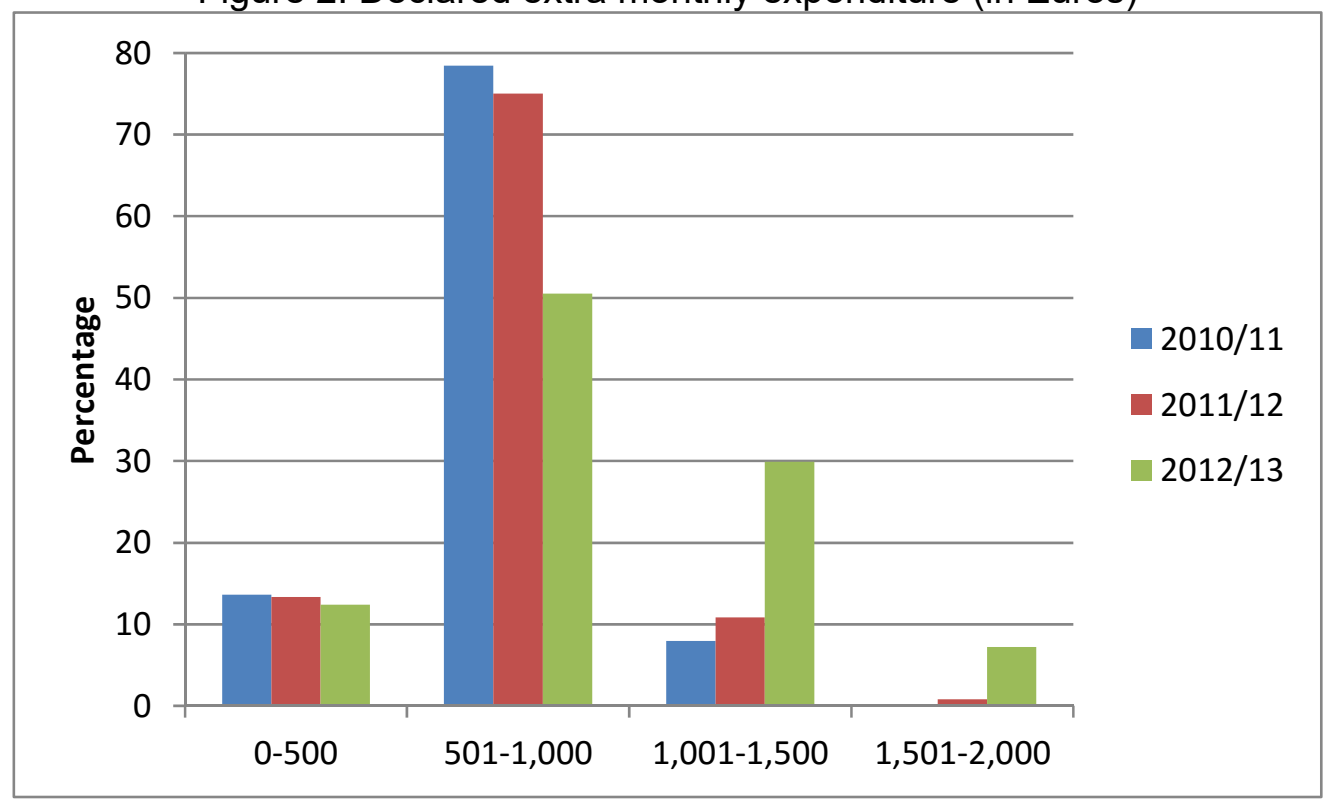

The Erasmus students' sample has been re-organized with a geographic proximity criterion as some countries only had one student during the three years that comprise the present study. So Slovakia and the Czech Republic have been grouped into Centre of Europe and Romany, Slovenia and Croatia into Balcan countries. But for Iceland and Lithuania the proximity criteria was not possible to use so they are not considered in the following analysis. 
Urquía-Grande, Elena; del Campo, Cristina. Erasmus programme effects: a Spanish case.

\section{RESULTS DISCUSSION}

Among all the questions included in the questionnaire the one about students' overall satisfaction with their Erasmus mobility stay was of the utmost importance. Over 80 per cent of the respondents (see Figure 3) valued their overall satisfaction with a six or a seven (out of seven) in each academic year with just a few responses below three. In fact they feel very satisfied with the experience, more integrated in Europe considering themselves more European, in line with Bache, (2006); Rienties et al. (2011); Wilson (2011); Kuhn (2012) and Schilde (2014) and with more socio-cultural and linguistic skills in line with Bennett et al. (2013) or Ippolito (2007) among others. To summarise, the students feel more prepared to have an international professional career development in line with Welch and Welch (2015); Papatsiba (2009) and Fernández, Pérez and Vaquero (2008).

Figure 3: Overall satisfaction with European stay experience

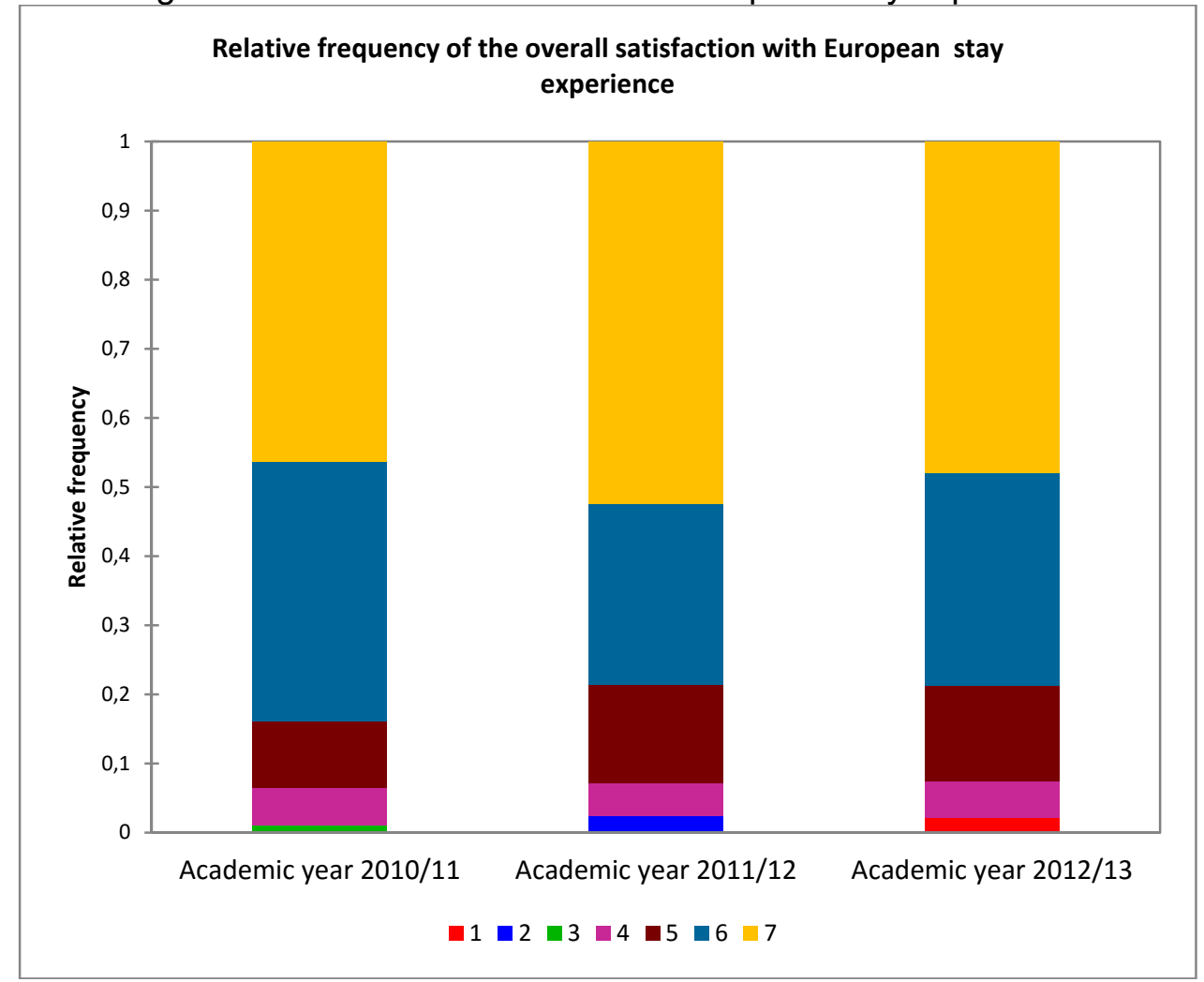

With respect to research question 1, whether students perceive their academic and socio-cultural adjustment differently between destination countries, a Kruskal-Wallis analysis was done by country. Kruskal-Wallis test(Cohen et al., 2000) is a nonparametric test for more than two samples that provides the same type of results as an analysis of variance, but based on the ranks and not the means of the responses. Significant differences ( $p$-value smaller than 0.05) were found for the academic environment and the students internationalisation (see Table 1). All students perceive that they develop the socio-cultural competences highly valuing their personal relation with the academic environment, this is with their lecturers and peers. Additionally they perceive a good level of student internationalisation in their host universities. Finally they positively value their personal experience in the whole stay in the host country. 
Urquía-Grande, Elena; del Campo, Cristina. Erasmus programme effects: a Spanish case.

Table 1: Kruskal-Wallis test of the variables determining socio-cultural competences developed by students

\begin{tabular}{lllll}
\hline & $\begin{array}{l}\mathrm{K}(\text { Observed } \\
\text { value })\end{array}$ & $\begin{array}{l}\mathrm{K} \text { (Critical } \\
\text { value })\end{array}$ & DF & $\begin{array}{l}\mathrm{p} \text {-value } \\
\text { (Two- } \\
\text { tailed) }\end{array}$ \\
\hline Academic environment & 26.496 & 23.685 & 16 & 0.022 \\
\hline $\begin{array}{l}\text { Internationalisation } \\
\text { environment }\end{array}$ & 27.226 & 23.685 & 16 & 0.018 \\
\hline Personal appraisal & 25.113 & 23.685 & 16 & 0.033 \\
\hline
\end{tabular}

There are countries where the academic environment is perceived as very high, such as in Central EU countries (see Table 2, where high values are highlighted in light grey). This fact can be due to the effort made by these universities to offer EMI courses, international degrees, and personal integration programs for international students together with the low cost of living. Portugal, on the other hand, is very low valued (low values are highlighted in Table 2 with dark grey). Our students explain that their instructors in many Portuguese universities still use their own language which many international students do not master.

Table 2: Socio-Cultural competences among countries

\begin{tabular}{llll}
\hline & $\begin{array}{l}\text { Academic } \\
\text { environment }\end{array}$ & $\begin{array}{l}\text { Internationalisation } \\
\text { environment }\end{array}$ & $\begin{array}{l}\text { Personal } \\
\text { appraisal }\end{array}$ \\
\hline Austria & $5.786(0.939)$ & $5.929(1.439)$ & $6.786(0.410)$ \\
\hline Balkans & $5.400(0.490)$ & $6.000(1.225)$ & $7.000(0.000)$ \\
\hline Belgium & $5.455(1.616)$ & $6.273(1.009)$ & $6.000(1.477)$ \\
\hline Central EU & $6.667(0.471)$ & $6.667(0.500)$ & $6.556(0.685)$ \\
\hline Finland & $6.125(1.111)$ & $6.563(0.814)$ & $6.733(0.573)$ \\
\hline France & $5.880(1.275)$ & $6.320(1.133)$ & $6.260(1.073)$ \\
\hline Germany & $6.346(0.731)$ & $6.346(1.018)$ & $6.385(0.923)$ \\
\hline Italy & $5.424(1.349)$ & $5.364(1.747)$ & $6.364(0.810)$ \\
\hline Netherlands & $6.129(0.955)$ & $6.571(0.772)$ & $6.662(0.740)$ \\
\hline Norway & $6.222(1.030)$ & $6.389(0.979)$ & $6.706(0.570)$ \\
\hline Poland & $6.000(1.000)$ & $6.500(0.798)$ & $7.000(0.000)$ \\
\hline Portugal & $4.667(0.943)$ & $6.333(1.155)$ & $6.333(0.471)$ \\
\hline Sweden & $5.800(0.980)$ & $6.500(0.889)$ & $6.632(0.741)$ \\
\hline Turkey & $5.333(1.2479$ & $6.667(0.577)$ & $6.000(0.816)$ \\
\hline UK & $5.667(1.054)$ & $6.593(0.747)$ & $6.222(1.165)$ \\
$*$ Mean values (standard deviations) & &
\end{tabular}

Turkey and Central EU countries have very high values of internationalisation environment in our students' perception. This is a consequence of a recent strategy implementation with high investments in internationalising their universities together 
Urquía-Grande, Elena; del Campo, Cristina. Erasmus programme effects: a Spanish case.

with teaching courses in English, the current "lingua franca" in Europe (Hellekjaer, 2010; ESN, 2016). Surprisingly, Italy is very low valued because their universities seem not to make a great effort to welcome incoming students.

Regarding personal appraisal, Balkans are the highest evaluated areas whereas Turkey and Belgium were the lowest ones. It is worth noting that those values are very high (above 6 out of 7 ) in all countries.

Regarding research question 2 (Do students perceive that they develop a linguistic competence as an internationalisation outcome?) students perceive that they have improved their linguistic competences. It is interesting to highlight that most of the students chose countries, such as Germany, France, Italy or Austria, where they could learn/practice the local language (their third language, L3) in line with Willis (2010) and Fernández, Fernández and Vaquero (2007). However, from the academic point of view, students choose universities with international degrees where the language of instruction is English, which they already master.

Currently, the linguistic improvement is one of the strategic lines within the Erasmus+ programme. Therefore, as part of the Erasmus application, students have to pass an on-line test before and after the academic stay to verify their linguistic competence and improvement in the language of instruction. If there is no improvement the Erasmus+ economic grant may be required to be reimbursed.

Nevertheless, the present research is more interested in knowing if students perceived whether they have improved their competence in the local language (L3). Therefore, a Friedman test (a non-parametric test similar to the parametric repeated measures ANOVA) was run. Significant differences were found in the language competence before and after the Erasmus stay, proving a significant increase (mean before the stay $=1.641$, mean after the stay $=2.741$ ) in their L3 command (see Table 3). Therefore, these students develop a competence to adapt to different environments which is an $\mathrm{HE}$ institutional rationale derived from the internationalisation strategy in line with Knight (2004). Additionally, this competence is nowadays increasingly valued among companies (Xiaochi, 2012).

Table 3: Friedman test

\begin{tabular}{ll}
\hline $\mathrm{Q}$ (Observed value) & 238.000 \\
$\mathrm{Q}$ (Critical value) & 3.841 \\
$\mathrm{DF}$ & 1 \\
$\mathrm{p}$-value (Two-tailed) & $<0.0001$ \\
\hline
\end{tabular}

In order to answer research question 3 (Which variables influence the students' overall satisfaction in host universities?) an ANCOVA test was run (An analysis of covariance tests the main and interaction effects of categorical variables on a continuous dependent variable, controlling for the effects of other continuous variables). The coefficient of determination indicates that 70 per cent of the initial dependent variable variability is explained by the independent variables. The Fisher's $F$ test is used to test if the explanatory variables bring significant information to the model. Given that the 
Urquía-Grande, Elena; del Campo, Cristina. Erasmus programme effects: a Spanish case.

probability corresponding to the $F$ value is lower than 0.0001 , we would be taking a lower than 0.01 per cent risk in assuming that the null hypothesis (no effect of the explanatory variables) is wrong. Therefore, we can conclude with confidence that the explanatory variables are significant. In order to make the final result easier to read only the significant variables are shown in Table 4.

Table 4: Variables determining overall satisfaction of international experience

\begin{tabular}{lllllll}
\hline Source & Value & $\begin{array}{l}\text { Standard } \\
\text { error }\end{array}$ & $\mathrm{T}$ & $\operatorname{Pr}>|\mathrm{t}|$ & $\begin{array}{l}\text { Lower } \\
(95 \%)\end{array}$ & $\begin{array}{r}\text { bound } \\
\begin{array}{l}\text { Upper } \\
(95 \%)\end{array}\end{array}$ \\
\hline $\begin{array}{l}\text { Academic } \\
\text { Environment }\end{array}$ & 0.101 & 0.036 & 2.829 & 0.005 & 0.031 & 0.171 \\
\hline $\begin{array}{l}\text { Academic } \\
\text { appraisal }\end{array}$ & 0.296 & 0.040 & 7.472 & $<0.0001$ & 0.218 & 0.374 \\
\hline $\begin{array}{l}\text { Personal } \\
\text { appraisal }\end{array}$ & 0.506 & 0.037 & 13.836 & $<0.0001$ & 0.434 & 0.578 \\
\hline $\begin{array}{l}\text { European } \\
\text { Integration }\end{array}$ & 0.213 & 0.040 & 5.289 & $<0.0001$ & 0.133 & 0.292 \\
\hline $\begin{array}{l}\text { Country2- } \\
\text { Austria }\end{array}$ & -0.093 & 0.033 & -2.854 & 0.005 & -0.157 & -0.029 \\
\hline $\begin{array}{l}\text { Country2- } \\
\text { Finland }\end{array}$ & -0.066 & 0.032 & -2.026 & 0.044 & -0.130 & -0.002 \\
\hline $\begin{array}{l}\text { Country2- } \\
\text { Germany }\end{array}$ & -0.091 & 0.033 & -2.739 & 0.007 & -0.156 & -0.026 \\
\hline $\begin{array}{l}\text { Country2- } \\
\text { Sweden }\end{array}$ & -0.078 & 0.033 & -2.406 & 0.017 & -0.142 & -0.014 \\
\hline
\end{tabular}

The variables which determine positively the students' overall satisfaction are the academic environment and appraisal, the personal appraisal and the European integration perception (see Table 4) in line with Rachaniotis et al. (2013) and Schilde (2014). Austria, Finland, Germany and Sweden negatively influence the students' overall satisfaction. That fact can be due to the higher cost of living in those countries, together with the colder weather conditions compared to Spain. The rest of the countries do not significantly influence this overall satisfaction. Moreover, when asked, some students answered that Austrian and German Universities are quite inflexible in the spectrum of accessible subjects. Also, these universities close enrolment for international students relatively soon, which causes them to look for new options in the last minute and this fact can be very stressful. The analysis was also done by gender but no differences were found.

Finally, with respect to research question 4 (What are the relations between the analysed variables? )a Multiple Correspondence Analysis (MCA) was run. MCA (Greenacre, 2007) works, for qualitative variables, in a similar way to principal components analysis. In MCA total inertia is defined and then it is decomposed optimally along so-called "principal axes" detecting and representing the underlying structures in the data set. Specifically, MCA assigns numerical scale values to the response of categorical variables, with certain optimal properties, that provide maps of the relationships between them. This is a method aimed specifically at quantifying categorical data, therefore only gender, country and stay extra cost were included in the analysis. The first two dimensions of this space (see Figure 4), explaining 62.37 per cent of the original adjusted inertia, are plotted to examine the associations among 
Urquía-Grande, Elena; del Campo, Cristina. Erasmus programme effects: a Spanish case.

the categories. The interpretation is based on points found in approximately the same direction from the origin and in approximately the same region of the space, although in this case the first axe explains already 43.15 per cent so this is the more explanatory dimension.

Figure 4: Multiple Correspondence Analysis

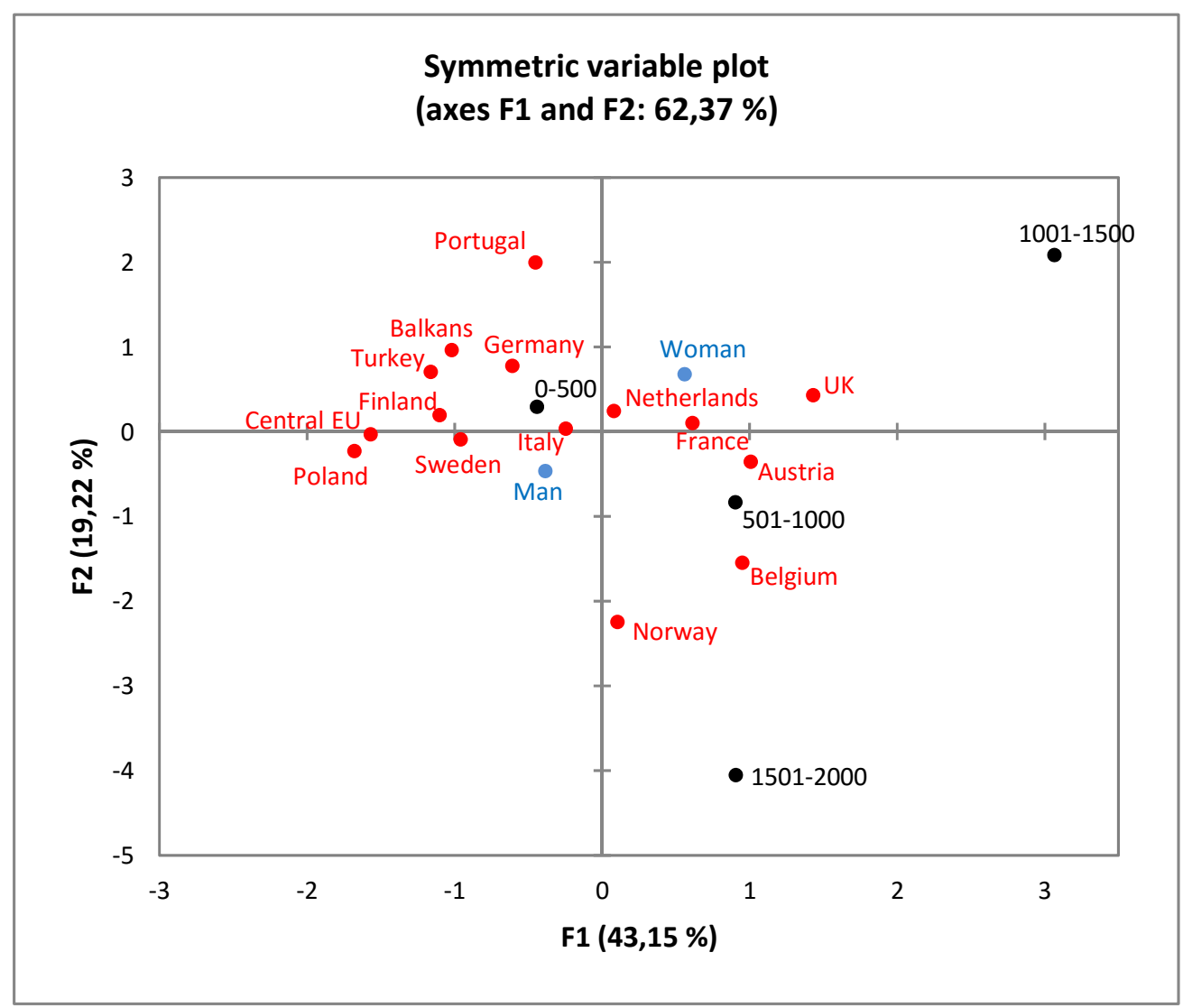

In this MCA it can be observed that female students tend to choose the Netherlands, France or the UK as main countries of destination of their Erasmus stay whereas male students prefer Italy or Sweden. The extra costs most students incur when living abroad are less than $500 €$ more than when living in Spain, although in Austria, Belgium and Norway that quantity rises to between $501 €$ and $1,000 €$. Additionally, a minority declare that they spend up to the range of 2,000€. Multiple reasons might justify these differences. Firstly, many universities and countries offer students either economical accommodation or living financial support. Secondly, many of the Spanish students still live with their parents so the extra cost of studying abroad is higher.

\section{CONCLUSIONS}

Students who study abroad understand and develop skills to study and work in a culturally diverse and different environment. Therefore, they perceive they develop socio-cultural competences and feel more international and European in line with 
Urquía-Grande, Elena; del Campo, Cristina. Erasmus programme effects: a Spanish case.

Campbell (2011), Bennet et al. (2013) and Leask (2009). Students who have studied in the Centre of Europe have culturally adjusted better while, surprisingly, students in Italy and Portugal, which are Mediterranean countries like Spain, valued lower the academic environment and students' level of internationalisation in the host universities. The result of those variables points to a more difficult integration in those universities, maybe because there are fewer international students and fewer English taught subjects. Instead Turkey has a high value in student internationalisation and a low value in personal appraisal indicating that this country has a high number of international students but cannot fully attend to all of them. The majority of the students perceive they improve their linguistic competences in the destination country language, independently of the country of destination, in line with Knight (2004) and Willis (2010).

Academic, cultural and integration experiences in the host universities determine the overall satisfaction perception of the students Erasmus stay in line with Rienties et al. (2011). The lowest valued countries are Austria, Finland, Germany and Sweden, probably due to their high cost of living. However, all previously mentioned factors develop students' competences and experiences in other European universities and contribute to increase their feeling of a European identity while also increasing their career opportunities in a European common labour market.

Additionally, in the open questions of the questionnaire the students propose as an improvement the decrease of bureaucracy in the Erasmus program and more flexibility in the subjects' equivalence for their own transcript of records. Also they propose more agreements of the universities with residences and to create a virtual platform to dialogue with Erasmus students who have gone previous years. Correlation among variables has shown that female students mainly choose the Netherlands, the UK and France as destination countries while male students mainly choose Italy and Sweden.

As future research lines, the Faculty of Economics and Business is designing another survey to analyse the in-coming Erasmus students' perception of their exchange stay in order to compare the results with the outgoing Erasmus students. Also, the survey will be implemented throughout all UCM faculties to be able to study possible differences among areas (Science, Humanities, Health and Arts). Another internationalisation strategy such as teaching staff mobility exchanges is also increasing and surveys should be done for them as well as comparing the teaching methodologies in order to design a best-practice guide to develop a deeper internationalisation strategy in line with key action two of the Erasmus+ 2014-2020 main objectives. 
Urquía-Grande, Elena; del Campo, Cristina. Erasmus programme effects: a Spanish case.

\section{REFERENCES}

Aerden, A., de Decker, F., Divis, J., Frederiks, M. and de Wit, H. (2013): 'Assessing the internationalisation from a Dutch-Flemish pilot certifying internationalisation', Compare, Vol. 43(1), 56-78.

Agnew, M. (2012): 'Strategic planning: An examination of the role of disciplines in sustaining internationalization of the University', Journal of Studies in International Education, Vol. 17(2), 183-202.

Airey, J. (2004): 'Can you teach it in English? Aspects of the Language Choice Debate in Swedish Higher Education', in R. Wilkinson (ed.), Integrating Content and Language: Meeting the Challenge of a Multilingual Higher Education (Maastricht, Netherlands: Maastricht University Press),97-108.

Airey, J. (2009): Science, Language and Literacy. Case studies of Learning in Swedish University Physics, Ph.D. publication, Uppsala Universitet, Sweden.

Albatch, P.G. and Knight, J. (2007): 'The Internationalization of Higher Education. Motivations and Realities', Journal of International Education, Vol. 11(3-4), 289305.

Allport, F. H. (1954): 'The structuring of events- outline of a general theory with applications to psychology', Psychological Review, Vol. 61(5), 281-303.

Bennett, R.J., Volet, S.E. and Fozdar, F.E. (2013): 'I'd say it's a kind of unique way: The development of intercultural student relationship', Journal of Studies in International Education, Vol. 17(5), 533-553.

Beerkens, H.J.J.G. (2004): Global opportunities and institutional Embeddedness: Higher Education consortia in Europe and Southeast Asia, Ph.D. thesis, Available at: http://doc.utwente.nl/50803/

Björkman, B. (2010): 'So you think you can EFL? English as a Lingua Franca as the medium of instruction', Journal of Language and Communication Studies, Vol. 45, 77-96.

Brandenburg, U. and de Wit, H. (2011):'The End of Internationalization', The International Journal of Higher Education, Vol. 62, 15-17.

Campbell, N. (2011): 'Promoting intercultural contact on campus: A project to connect and engage international and host students', Journal of Studies in International Education, Vol. 20(10), 1-23.

Chirkov, V.I., Safdar, S., De Guzman, J. and Playford, K. (2010):'Further examining the role motivation to study abroad plays in the adaptation of international students in Canada', International Journal of Intercultural Relations, Vol. 32, 427-440.

Cohen, L., Manion, L., and Morrison, K. (2000): Research methods in Education, Routledge Falmer, London.

Dafouz, E., Camacho, M.M. and Urquía, E. (2013): 'Surely they can't do as well: a comparison of business students', Language and Education, Vol. 28(3), 223236.

Deardorff, D. (2006): 'Identification and assessment of intercultural competence as a student outcome of internationalization', Journal of Studies in Higher Education, Vol. 10, 241-266.

Erasmus Student Network (2016): 'ESN Annual Report 2015-2016’ 
Urquía-Grande, Elena; del Campo, Cristina. Erasmus programme effects: a Spanish case.

Ericsson, E. (2000): 'Demands for Intercultural Communicative Competence in working life: Some experiences of Swedish Higher Education co-operation with Baltic neighbour, Estonia', International Perspectives on competence in the workplace, 241-258.

European Commission (2013): Erasmus+: The EU programme for Education, Youth and Sport 2014-2020.

European Union (2014):'The Erasmus impact study'. Publications Office of the European Union, Luxembourg.

Fernández López, S.; Pérez Esparrells, C. and Vaquero García, A. (2009): 'Movilidad internacional de la Universidad Española: Análisis regional e institucional del programa Socrates-Erasmus. Revista de Estudios Regionales, Vol. 85, 143172.

Fernández López, S.; Fernández Alfaro,S. and Vaquero García, A. (2007): 'Proyección internacional de los sistemas de Educación Superior de América Latina y el Caribe'. Revista Iberoamericana de Educación, Vol. 45, 159-175.

Fernández López, S. and Ruzo Sanmartín, E. (2003): 'Los procesos de Internacionalización y Globalización en la Educación Superior: Un análisis de los países OCDE'. Revista de Educación, Vol. 335, 385-413.

García, F.J., Kümbül, T., Mendoza-Jimenez, J. and Yataganbaba, E. (2013): 'A whole world outside home: factors attracting Erasmus students and their effects on intercultural competence, language learning, economy and Tourism'. EDULEARN 13 Proceedings, 3726-3734.

Greenacre, M. (2007): Correspondence Analysis in Practice, Second Edition, Chapman and Hall, London.

Halualani, R.T. (2008): 'How do multicultural university students define and make sense of intercultural contact? A qualitative study', International Journal of Intercultural Relations, Vol. 32, 1-16.

Hellekjaer, G.O. (2010): 'Language Matters Assessing lecture comprehension in Norwegian English-Medium Higher Education' in Dalton-Puffer, C., Nikula, T. and Smit, U. (eds) Language Use in Content-and-Language-Integrated Learning (CLIL), 233-258.

Ippolito, K. (2007): 'Promoting intercultural learning in a multicultural university: ideals and realities', Teaching in Higher Education, Vol. 12(5-6), 749-763.

Keating, A. (2009): 'Educating Europe's citizens: moving from national to post-national models of education for European citizenship', Citizenship Studies, Vol. 13(2), 135-151.

Kimmel, K., and Volet, S.E. (2012):'Understanding motivation, engagement and experiences of intercultural interactions at university: A person-in-multiple contexts perspective', European Journal of Psychology of Education, Vol. 27, 227-245.

Knight, J. (2004): 'Internationalization remodelled: Definition, Approaches and Rationales', Journal of Studies in International Education, Vol. 8(1), 5-31.

Knight, J. (2008): 'Higher Education in turmoil: The changing world of internationalization', Sense Publishers, Rotterdam.

Knight, J. and de Wit, H. (1995): 'Strategies for internationalization of Higher Education: Historical and conceptual perspectives'. In de Wit, H. (ed) Strategies for Internationalisation of Higher Education: of Higher Education. A Comparative 
Urquía-Grande, Elena; del Campo, Cristina. Erasmus programme effects: a Spanish case.

Study of Australia, Canada, Europe and the United States of America, 5-32, European Association for International Education, Amsterdam.

Kuhn, T. (2012): 'Why Educational Exchange Programmes miss their mark: Crossborder Mobility, Education and European identity', Journal of Common Markets Studies, Vol. 50(6), 994-1010.

Leask, B. (2009): 'Using formal and informal curricula to improve interactions between home and international students', Journal of Studies in International Education, Vol. 13(2), 205-221.

Maiworm, F. and Wächter, B. (2002): English-Language-Taught Degree Programmes in European Higher Education: Trends and Success Factors, Lemmens, Bonn.

Montgomery, C. and McDowell, L. (2009):'Social networks and the international student experience: An international community of practice?', Journal of Studies in International Education, Vol. 13, 455-466.

Musselin, C. (2004): 'Towards a European academic labour market? Some lessons drawn from empirical studies on academic mobility', The International Journal of Higher Education, Vol. 48, 55-78.

Papatsiba, V. (2005): 'Political and Individual rationales of student mobility: A case study of Erasmus and a French regional scheme for studies abroad', European Journal of Education, Vol. 40(2), 173-88.

Papatsiba, V. (2009): 'European Higher Education Policy and the formation of Entrepreneurial students', European Educational Research Journal, Vol. 8(2), 189-203.

Parsons, R.L. (2010): 'The effects of an internationalized university experience on domestic students in the United States and Australia', Journal of Studies in International Education, Vol.14, 313-334.

Pépin, L. (2007): 'The History of EU cooperation in the field of Education and Training: How Lifelong Learning became a strategic objective', European Journal of Education, Vol. 42(1), 121-132.

Petit, I. (2007): 'Mimicking History: The European Commission and Its Education Policy', World Political Science Review, Vol. 3(1), 1-25.

Rachaniotis, N.P.,Kotsi,F. and Agiomirgianakis, G.M. (2013): 'Internationalization in tertiary education: Intra-European students mobility', Journal of Economic Integration, Vol. 28(3), 457-481.

Schilde, K.E. (2014): 'Who are the Europeans? European Identity outside of European integration', Journal of Common Studies, Vol. 52(3), 650-667.

Summers, M. and Volet, S. (2008): 'Students'attitudes towards culturally mixed groups on international campuses: impact of participation in diverse and non-diverse groups', Studies in Higher Education, Vol. 33(4), 357-370.

Walkenhorst, H. (2008): 'Explaining change in EU education policy', Journal of European Public Policy, Vol. 15(4), 567-587.

Wilkinson, R. (ed.) (2004): Integrating Content and Language. Meeting the Challenge of Multilingual Higher Education, UniversitairePers, Maastricht.

Wilkinson, R. and Zegers, V. (eds) (2007): Researching Content and Language Integration in Higher Education, UniversitairePers, Maastricht.

Willis, H. (2010): 'What shapes short term study abroad experiences? A comparative case study of students' motives and goals', Journal of Studies in International Education, Vol. 14(5), 452-470. 
Urquía-Grande, Elena; del Campo, Cristina. Erasmus programme effects: a Spanish case.

Wilson, I. (2011): 'What should we expect of 'Erasmus Generations'?', Journal of Common Market Studies, Vol. 49(5), 111-340.

De Wit, H. (2011): 'Globalización e internacionalización de la educación superior'. Revista de Universidad y Sociedad del Conocimiento, Vol. 8(2), 241- 247 (in Spanish).

Xiaochi, Z. (2012): 'Discussion on International Internship and Intercultural Competence from a perspective of Higher Education internationalization- $A$ case study of the program work and travel USA', Cross-Cultural Communication, Vol. 8(5), 62-66.

Yusliza, M.Y. and Shankar, C. (2010): 'Adjustment in international students in Malaysian Public University', International Journal of Innovation, Management and Technology, Vol. 1(3), 275-278. 